橋本 博 史 ${ }^{* 1} \cdot$ 吉 木 敬*2

鈴木 和 男*3 ・徳永 勝士*4 - 有村 義宏*5

吉田 雅治*6 ・沼野藤夫*7 ・安田 慶秀*8

中林 公正 ${ }^{* 5}$ 小林 茂人*1 居石 克夫*9

津坂 憲政*10 ・ 中島伸 之*11 重松宏*12

小 林 靖*7 由 谷 親夫*13 - 能勢 負 ${ }^{* 14}$

尾崎 承一*15 - 金井芳之*16 濱野慶朋*17

鈴木 登*18 - 松岡康夫*19.吉田俊治*20

川崎富夫*21・森下竜一*22・東みゆき*23

西村 泰治 ${ }^{* 24}$ ・稲 葉 裕 ${ }^{* 25}$ ・福原 俊一*26

Jpn. J. Clin. Immun., 24 (6) : 336 346, 2001.

I .はじめに

厚生労働省厚生科学特定疾患対策研究事業による難 治性血管炎に関する調查研究班は，今年度 3 年目を迎 えた. 当研究班の研究目的は, これまでの難治性血管 炎に関する研究成果を市まえ難治性血管炎の成因と病 態発症機序の解明を図り，その成果を臨床的診断と治 療に還元し，さらなる患者の予後の改善とQOL の向 上を目指すことにある．対象とする疾患は多岐にわた るが，特に大型血管炎では高安動脈炎を，中・小型血 管炎では抗好中球細胞質抗体 (ANCA) 関連血管炎 \{頭微鏡的多発血管炎 (MPA)，ウェゲナー肉芽腫症
(WG)，アレルギー性肉芽腫性血管炎（AGA，チャ ーグ・ストラウス症候群) \}に関する研究を重点課題 としている.そして，研究テーマを絞り以下の小委員 会を設置し研究を進めてきた。

1）病因・病態に関する小委員会（吉木敬委員長）, 2）抗好中球細胞質抗体（ANCA）に関する小委員 会，(1）ANCA の基礎的検討小委員会（鈴木和男委員 長)，(2) ANCA 関連血管炎の遺伝的解析に関する小 委員会 (徳永勝士委員長), (3) ANCA 測定法に関す る小委員会 (有村義宏委員長)，(4) ANCA 関連血管 炎の治療に関する小委員会 (吉田雅治委員長)，3）臨 床（難治性血管炎の疫学, 病態, 診断, 治療, QOL

*1順天堂大学膠原病内科, ${ }^{* 2}$ 北海道大学大学院医学研究科病態解析学, ${ }^{* 3}$ 国立感染症研究所生体防御物質 室, ${ }^{* 4}$ 東京大学大学院医学研究科人類遺伝学, ${ }^{* 5}$ 杏林大学第一内科, ${ }^{* 6}$ 東京医科大学八王子医療センター腎臓 科, ${ }^{* 7}$ 東京医科歯科大学第三内科, ${ }^{* 8}$ 北海道大学大学院医学研究科循環器外科, ${ }^{* 9}$ 九州大学大学院医学研究科 病理病態学, ${ }^{* 10}$ 埼玉医科大学総合医療センター第二内科, ${ }^{* 11}$ 千葉大学第一外科, ${ }^{* 12}$ 東京大学血管外科, ${ }^{* 13}$ 国 立循環器病センター臨床検査部, ${ }^{* 14}$ 愛媛大学第二病理学, ${ }^{* 15}$ 聖マリアンナ医科大学りウマチ・膠原病・アレ ルギー内科, ${ }^{* 16}$ 東京大学医科学研究所七卜疾患モデル研究センター, ${ }^{* 17}$ 順天堂大学第二病理学, ${ }^{* 18}$ 聖マリア ンナ医科大学免疫学・病害動物学, ${ }^{* 19} 川$ 川崎市立川崎病院内科, ${ }^{20}$ 藤田保健衛生大学感染症・リウマチ科, ${ }^{* 21}$ 大阪大学血管外科, ${ }^{* 22}$ 大阪大学大学院医学研究科加齢医学, ${ }^{* 23}$ 東京医科歯科大学大学院医歯学総合研究科分 子免疫分野, ${ }^{* 24}$ 熊本大学大学院医学研究科免疫識別学, ${ }^{* 25}$ 順天堂大学衛生学, ${ }^{* 26}$ 京都大学大学院医学研究科 理論疫学分野 $(2001 \cdot 8 \cdot 10$ 受理) 


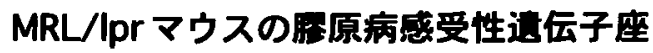

-MRL/Ipr x (MRL/Ipr x C3H//pr)F1, (MRL/lpr x C3H/lpr)F2マウスによるー

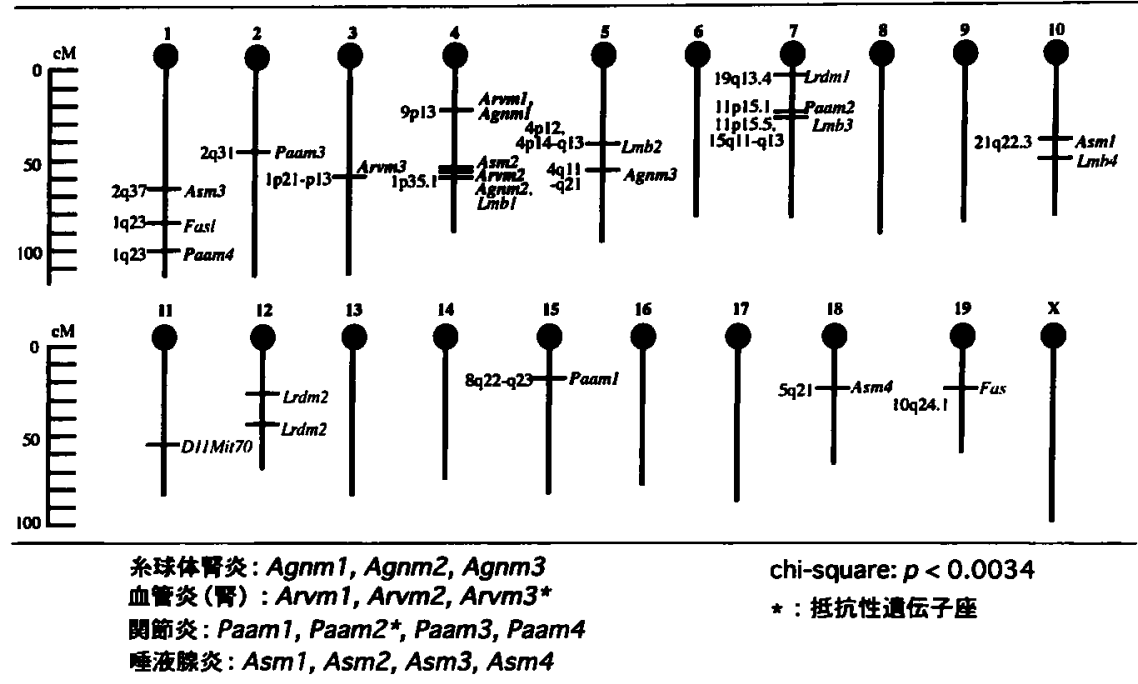

図 1

など）に関する小委員会，(1) 大型血管炎に関する小 委員会 (安田慶秀委員長)，(2) 中・小型血管炎に関す る小委員会 (中林公正委員長) である.また, 病因・ 病態に関する研究では横断的基盤研究班より, QOL 評価票作成ては特定疾患に関する疫学研究班㭁よび特 定疾患患者の QOL の判定手法の開発に関する研究班 より研究協力者の参画を得て研究を進めた。さらに, ANCA 関連血管炎の遺伝的解析と ANCA の測定法 の検討に際しては，以下の研究協力者との共同研究で 行った. 前澤晃 (群馬大学第三内科), 槙野博史 (岡 山大学第三内科), 杉崎徹三 (昭和大学腎葴内科), 杉 山隆夫（国立療養所下志津病院りウマチ科），下条直 樹 (千葉大学小児科), 岡村春樹 (兵庫医科大学生体 防御部門), 堀田修 (仙台社会保険病院腎センター), 八田和大 (天理よろず相談所病院総合内科), 徳田道 昭 (香川医科大学第一内科), 佐中改 (東京女子医科 大学第二病院内科).

ここでは，各小委員会における最近の知見を中心に 述べる1-3).

\section{1. 病因・病態に関する知見}

血管炎の病因・病態の解明を目的として，血管炎感 受性遗伝子ゃANCA 産生感受性遺伝子などの遺伝子 解析, 血管炎の発症や病態に関わる新しい分子につい ての解析，抗クロマチン抗体やANCA，抗血管内皮
細胞抗体 (AECA) など自己抗体の解析, 胸腺や $\mathrm{T}$ 細胞などが関与する主として細胞性免疫異常などの解 析を行ってきた.

1）血管炎の発症・病態に関与する遺伝子の解析 膠原病のモデルマウス MRL/lpr は血管炎, 系球体 腎炎, 関節炎, 唾液腺炎などを認めるが, 血管炎は他 の膠原病病態とは遺伝的に分離して発症しポリジーン 遺伝であることを明らかにした（図 1)。すなわち， 血管炎は少なくとも第 4 染色体上の 2 つの感受性遺伝 子座 Arvm 1, Arvm 2 と第 3 染色体上の 1 つの抵抗 性遺伝子に支配されており，これらの遺伝子座は各々 一つでは遺伝的浸透度は低いが，3つあわさって相補 的に作用し，発症率，重症度を堌すという相加性を示 す.さらに，位置的候補遺伝子として遺伝子多型の著 しいCD 72 を明らかにした。 CD 72 は, B 細胞の活 性化に負のシグナルを伝達する分子であり, MRL/ $1 \mathrm{pr}$ マウスでは細胞外領域に 7 個のアミノ酸欠失を含 む多型を示した，一方，血管炎のキャリバーの特異性 からみると, Arvm 1 は大動脈主分枝の大型血管炎と 腎動脈の血管炎とを共有するが，Arvm 2 は後者にの み感受性を示し，血管キャリバー別に血管炎の発症を 規定している遺伝子の存在も示唆された。

(NZBxW) F 1 xNZW 退交配マウスを用い, ヒト myeloperoxidase (MPO) とマウスMPOを標的と した MPO-ANCA 感受性遺伝子のマッピングを行っ 
た. その結果，マウス第 7 染色体のセントロメア側に MPO-ANCA 産生感受性領域の座位が同定された (ロッドスコア 2.2).この座位は D 7 MIT 21 に連銷 しており，このマーカーの遺伝子型により，WW 型 (NZW/NZW ホモ型) と BW 型 (NZB/NZWへテ 口型）の 2 群に退交配マウスを分類すると，WW 型 群が有意に高いMPO-ANCA力価を示した（p< 0.005)。この近傍には Cd 22, Tgfb 1, Il 11, Cd 79 a, Idd 7 などの免疫調節性遺伝子ゃ自己免疫疾患関 連遺伝子が存在する.今後, これら動物モデルに相同 するヒトの遺伝子の解析が進められるものと思われ る.

2）血管炎の発症・病態に関与する新しい分子の解 析

血管炎の発症には血管内皮細胞（EC）の傷害が重 視される. その傷害には炎症性サイトカインの刺激に よる種々の接着分子の発現, 白血球の浸潤, 種々の化 学伝達物質, 活性酸素, NO など多くの因子が関与す る。当研究班では, 新しい B 7ファミリ一分子 B 7 h，B 7-H 1 の血管内皮細胞（HUVEC）における発 現と機能について検討した. HUVECにより誘導さ れる SEB 刺激 CD 4 陽性 $\mathrm{T}$ 細胞の増殖反応は, B $7 \mathrm{~h}$ のリガンドであるICOS に対する抗体で抑制されるこ とから, ICOS-B $7 \mathrm{~h}$ が T 細胞と血管内皮細胞との相 互反応に関与している可能性が示された.

虚血および低酸素でのストレス応答を細胞レベルで 解析した過程で，低酸素関連分子として ORP 150 を, 低酸素・再酸素化関連分子として RA 301/Tra $2 \beta$ を 見いだした.これらの分子の血管病変における発現を 検討すると, 前者は低酸素により誘導される血管新生 において VEGF の裏方分子として働いている可能性 が示唆され, 後者は低酸素負荷後再酸素化にて誘導さ れる分子で，血管障害後の新生内膜のみならず早期に おける外膜の myofibroblastにも認められ, tissue remodeling の指標となることが示晙された。

3）血管炎の発症・病態に関与する自己抗体の解析

血管炎と関連する自己抗体として ANCA，AECA の他に抗 DNA 抗体を含む抗核抗体があげられる。抗 原の供給の観点からアポトーシスによるヌクレオソー ムが注目され，核クロマチンの意義は無視できない。 壊死性血管炎・糸球体腎炎モデルマウス（Nuc-KO） では，抗ヒストン H 3 ダイマー（H 3 D) 抗体は血管 炎発症直前の 12 週令で増強され, さらにその直前に 抗サブヌクレオゾーム (SNS) 抗体の増加が認めら
れた. 一方，血管炎の主要組織である腎から抽出した 抗体は経時的に増加し，中でも増強をみたアイソタイ プは G 3 であった．血管炎の病態では H 3 D と SNS の関与が示唆された。

MRL/lpr マウスの血清では, p (perinuclear) ANCA 力価と抗 (high mobility group protein) HMG 1/HMG 2 抗体価とが有意の相関を示し，血清 をあらかじめ HMG 1/HMG 2 で吸収すると pANCA の力価の減弱が認められた。このことから，MRL/ lpr における pANCA の主たる対応抗原は HMG 1/ HMG 2 であることを明らかとなり，MRL/lpr マウ スでみられる血管炎の発症機序がヒト ANCA 関連血 管炎と異なることが示唆された。

AECA について, 臍帯静脈内皮細胞膜を抗原とし た SDS ポリアクリルアミドダル電気泳動を用いた Western blot 法で測定したところ, 抗 $74 \mathrm{kDa}$ 抗体が 高安動脈炎患者血清に高率に，かつ特異的に検出され た. 現在, その対応抗原のアミノ酸配列を解析中であ る.

\section{4）血管炎の発症・病態に関する細胞性免疫異常の 解析}

HTLV-1 env-pX 遺伝子導入ラット（env-pX ラッ ト）は血管炎発症モデル動物として確立したものであ り，レトロウイルスの病因的関与が強く示唆されてい る.しかしながら，このラットにみられる血管炎はり ンパ球などのエフェクター細胞のみの env-pX 遺伝子 発現では発症しないことが明らかにされている。そこ で, この env-pX ラットと同系正常ラットとの間で, 胸腺置換と骨髄移植を組み合わせ, 胸腺のフレームワ ークにのみ env-pX 遺伝子を発現するラットを作成し たところ，このラットに壊死性血管炎の発症を認め た. 従って, env-pX ラットの壊死性血管炎は, リン 八球が胸腺で分化する過程において, env-pX 遺伝子 を発現する胸腺フレームワークを通過することによ り，自己の血管構成成分に対する反応性を有した状態 で末梢に出現するために発症する自己兔疫疾患と考え られた。

Lewis ラットの胸部大動脈由来血管平滑筋細胞株を $\mathrm{MRL} / \mathrm{n}$ マウスに免疫し, 所属リンパ節細胞をin vitro で抗原提示細胞の存在下で血管平滑筋細胞抗原 で刺激を繰り返し，CD 4 陽性 $\mathrm{T}$ 細胞 ライン （MV 1）を樹立した。抗原特異的に活性化した MV 1 は, in vitroでは, CD 4 依存的な増殖・Th 1 サイト カインの産生・Fas 陽性標的細胞の killing を示し, 


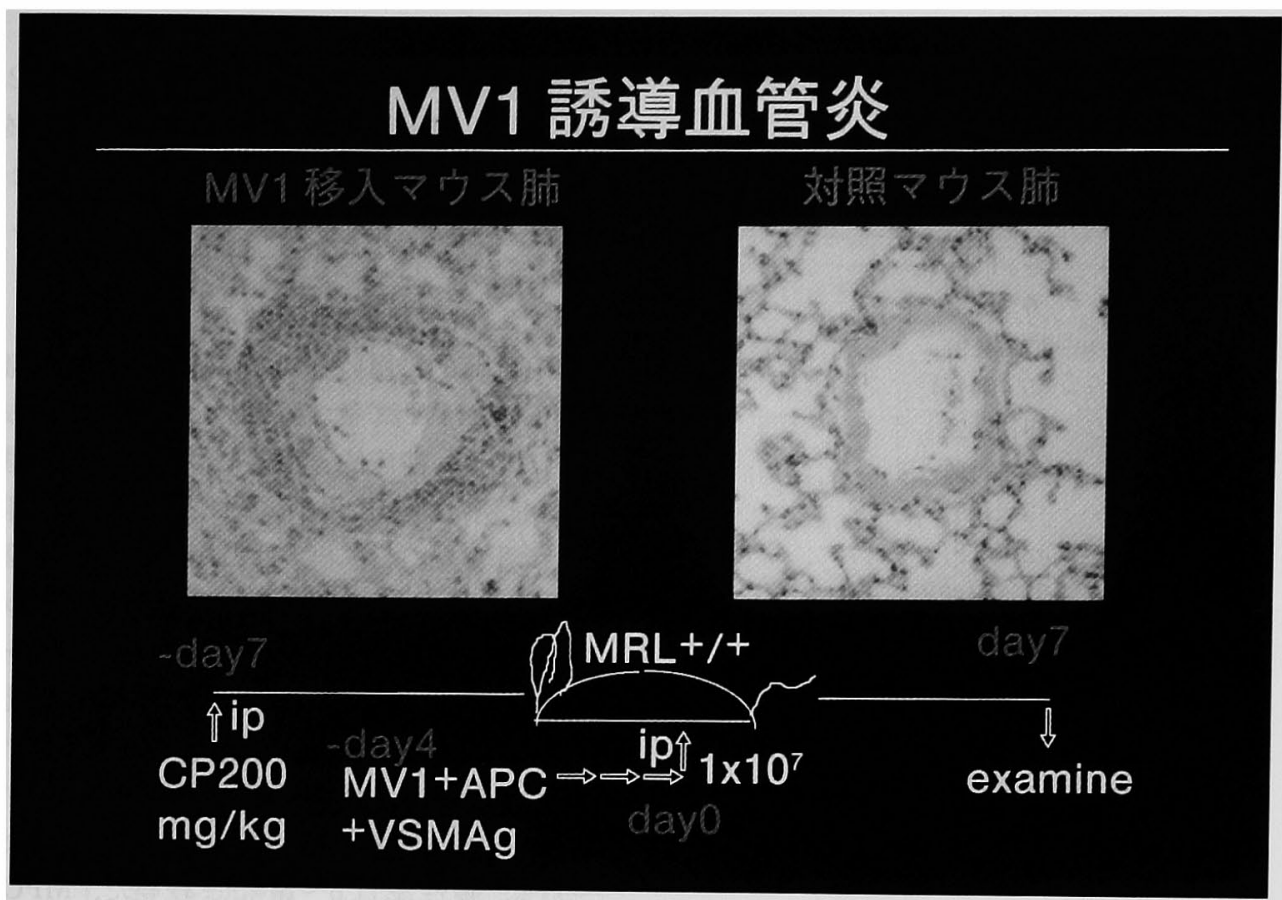

図 2 活性化 MVI をシクロフォスファミド処理 MRI+/+マウスの腹腔内に移入すると 肺にのみ血管炎がみられた (左). 右は対照マウス.

in vivo では，受身移入された同系マウスの肺の小動 脈周囲に血管壁構造の破壊を伴うリンパ球浸潤を惹起 することを認めた（図 2). 以上より，MV 1 は血管 炎惹起性を有する細胞障害性 CD 4 陽性 $\mathrm{T}$ 細胞である ことが明らかとなり, 今後 MV 1 の認識抗原の解析 を行う予定である.

血管炎を有する SLE患者 $\mathrm{T}$ 細胞では, 短い3’ UTR をもつ 5 鎖 mRNA が有意に多く発現している ために $\xi$ 鎖 mRNA の安定性，輸送，あるいは局在に 異常が生じ, $\xi$ 鎖の発現低下が起こると考えられる. $\xi$ 鎖発現低下に伴うシグナル伝達異常によって活性化 されたVLA-4 などの接着分子により血管炎病態が惹 起されている可能性がある。

\section{ANCA に関する知見}

1） ANCA の基礎的検討

病態に密接に関係する各種 ANCA の反応するエピ トープの解析を行った. MPO-ANCAに関しては, $\mathrm{MPO}$ の $\mathrm{H}$ 鎖 $\mathrm{N}$ 末端領域の細フラグメントである H 4 p 1-H 4 p 10 を合成し, これらの合成断片を患者 血清とあらかじめ反応させ, その後エピトープ解析用 のELISA に供しその阻害から反応部位を検索した.
その結果，MPOのH鎖 N末フラグメント $(\mathrm{H}-4)$ の 4 番目の断片 $4 \mathrm{P} 4$ が血管炎の病態と関連することを 明らかにした。

一方, WGに特異的とされる PR 3-ANCA が反応 するエピトープの解析をヒト好中球エラスターゼ (HLE) のキメラ蛋白を作成して検討した. その結 果, PR 3-ANCA 陽性血清は 5'PR 3 cDNA/3'HLEcDNA と 5'HLEcDNA/3'PR 3 cDNA のキメラ蛋白と の反応性を認め, エピトープに多様性があること, PR 3 酵素活性に及ぼす影響も多様であることを認め た.

また，抗 HMG 1/HMG 2 抗体のエピトープ解析を リコンビナント蛋白断片を用いて行った結果, HMG 1 の 84-88, HMG 2 の 83-88 のアミノ酸がエピ トープの一部であることを明らかにした。

エピトープの解析に加えモデルマウスによる発症機 構の解析を行った. 腎炎や血管炎ををきたし MPOANCA 抗体を認めるNZB/WF 1, MRL, SCG/ $\mathrm{Kj}$, IRF-8/ICSBP マウスやCandida albicans 由来 分子誘発の冠動脈炎マウスを用いて血管炎発症への MPO-ANCA の関与を検討すると共に, MPO 遺伝 子欠損マウスを作成しその解析を試みた。 その結果, 
表 1 HLA-DRB 1 allele positivity in Japanese patients with microscopic polyangiitis (MPA)

\begin{tabular}{lcrll}
\hline DRB 1 & $\begin{array}{c}\text { MPA (\%) } \\
(\mathrm{n}=42)\end{array}$ & $\begin{array}{c}\text { controls }(\%) \\
(\mathrm{n}=265)\end{array}$ & $\mathrm{P}^{*}$ & Pc \\
\hline 0101 & $4(9.5)$ & $26(9.8)$ & & \\
0401 & $3(7.1)$ & $6(2.3)$ & & \\
0403 & $2(4.8)$ & $13(4.9)$ & & \\
0405 & $6(14.3)$ & $65(24.5)$ & & \\
0406 & $1(2.4)$ & $19(7.2)$ & & \\
0407 & $3(7.1)$ & $6(2.3)$ & & \\
0410 & $1(2.4)$ & $5(1.9)$ & & \\
0802 & $4(9.5)$ & $18(6.8)$ & & \\
0803 & $7(16.7)$ & $37(14.0)$ & & \\
0901 & $23(54.8)$ & $77(29.1)$ & 0.001 & 0.022 \\
1101 & $3(7.1)$ & $5(1.9)$ & 0.08 & \\
1201 & $1(2.4)$ & $19(7.2)$ & & \\
1202 & $1(2.4)$ & $11(4.2)$ & & \\
1302 & $3(5.4)$ & $51(19.2)$ & 0.08 & \\
1401 & $1(2.4)$ & $13(4.9)$ & & \\
1403 & $2(4.8)$ & $10(3.8)$ & & \\
1405 & $0(0)$ & $17(6.4)$ & & \\
1406 & $0(0)$ & $7(2.6)$ & & \\
1501 & $7(16.7)$ & $29(10.9)$ & & \\
1502 & $7(16.7)$ & $54(20.4)$ & & \\
1602 & $0(0)$ & $8(3.0)$ & & \\
others & $1(2.4)$ & $13(4.9)$ & & \\
\hline & & & &
\end{tabular}

MPO 遺伝子欠損マウスにおいてもMPO-ANCA が 血管炎に関わり，MPO-ANCA 産生に MPOが抗原 の一つになっていることを明らかにしたままた，好中 球異常を示す転写因子 IRF-8/ICSBP の欠損マウスに おいても MPO-ANCA が加齢と共に上昇することを 認め, 好中球異常も MPO-ANCA 産生に関与してい ることが示唆された.

\section{2） ANCA 関連血管炎の遺伝子解析}

2001 年 6 月までに研究協力施設より供与された ANCA 関連血管炎患者 73 例について, HLADRB 1, TNF $\alpha$ promoter (TNFA), TNF receptor II (TNFR 2), Fc $y$ receptor II a (FCGR $2 \mathrm{~A}$ ), IIb (FCGR 2 B), IIIa (FCGR 3 A), IIIb (FCGR 3 B) の多型を検討した，現在解析途中であるが，42 例の MPA 症例は, HLA-DRB $1 * 0901$ と有意の正の相 関を認めている $\left(\mathrm{p}=0.001, \mathrm{Pc}_{\mathrm{c}}=0.022\right.$, odds'ratio 2.96）(表 1).また, DRB $1 * 0901$ との関連は, MPA 以外の疾患を含めた pANCA 陽性者 60 例の解 析においても認められ，MPA 以外では AGAに陽性
例が高い.

一方, TNFA 5'flanking region, TNFR 2, Fc $\gamma R$ IIa，IIb，IIIa，IIIbについては有意の相関を認めな かったものの, pANCA 陽性者における Fc $\gamma$ R IIIbNA $2 / 2$ 遺伝子型の減少傾向が検出された $(\mathrm{p}=$ $0.06)$.

\section{3） ANCA 測定法に関する検討}

現在臨床的に用いられている市販 ANCA 測定試薬 (MPO-ANCA 試薬 3 種類, PR 3-ANCA 試薬 4 種 類）の精度，臨床的有用性について ANCA 関連血管 炎 49 症例，血清 82 検体を対象に検討した，同時再現 性, 希釈試験，日差再現性の検討では，各試薬いずれ の施設においても変動係数 (CV) が国際的ガイドラ インの基準（20\%以下）を満たし良好であったが， MPO-ANCA 試薬はPR 3-ANCA 試薬に比べやゃ $\mathrm{CV}$ が高く，更なる精度改良が必要と思われた。 MPO-ANCA の定性完全一致率は 88〜90\% で，陽性 率は 50〜62\%, PR 3-ANCA の定性完全一致率は 87 〜95\%, 陽性率は 5〜16\%であった. MPO-ANCA の定性完全一致率，陽性率は活動期には高い率を示し たが，非活動期にはやや低い傾向が認められた。しか しながら試薬間に有意の差はなかった。

また，MPO-ANCA の抗体価はいずれの試薬も疾 患活動性とよく相関した（表 2)。試薬間における MPO-ANCA の測定值はよく相関したが，相互の互 換性は設定し得なかった。

\section{4） ANCA 関連血管炎の治療に関する検討}

ANCA 関連血管炎の主たる治療法は，ステロイド 薬と免疫抑制薬による抗炎症療法，免疫抑制療法であ る.これらの治療法は非特異的治療法であるが，適切 な用法，用量により生命予後の改善が指摘され，特 に，ステロイド多量投与とシクロフォスファミド （CP）の併用療法が注目されている.しかしながら, 長期寛解導入を目標とした場合には，寛解後の再燃， 薬郕の副作用，特に重篤な感染症の併発などが問題と なる，そこで当小委員会では， evidence based medicine（EBM）に基づきANCA 関連血管炎における免 疫抑制療法の有用性を検討した。その結果，免疫抑制 薬使用例は有意に軽快例が多く，特にステロイド薬と シクロフォスファミド (CP) の経口投与ないしCP のパルス療法は寛解率が高く, 生命予後も良好で, 寛 解維持にも有用であることを明らかにした。また， $\mathrm{CP}$ のパルス療法は CP の経口投与に比べ副作用が少 ないと考えられた。合併症として呼吸器感染症，特に 
表 2 疾患活動性と MPO-ANCA 值

( $\mathrm{n}=54$ : 活動期 22 例, 非活動期 32 例)

\begin{tabular}{|c|c|c|c|c|c|c|c|}
\hline & \multicolumn{2}{|c|}{$\begin{array}{c}\text { 試薬 } \mathrm{A} \\
\text { (陽性: } \geqq 20 \mathrm{EU})\end{array}$} & \multicolumn{2}{|c|}{$\begin{array}{c}\text { 試薬 } \mathrm{B} \\
\text { (陽性 }: \geqq 9 \mathrm{U} / \mathrm{m} l \text { ) }\end{array}$} & \multicolumn{2}{|c|}{$\begin{array}{c}\text { 試薬 } \mathrm{C} \\
(\text { 陽性： } \geqq 6 \mathrm{U} / \mathrm{m} l)\end{array}$} \\
\hline & & 活動期 & 非活動期 & 活動期 & 非活動期 & 活動期 & 非活動期 \\
\hline \multirow{8}{*}{$\begin{array}{l}\text { 施 } \\
\text { 設 }\end{array}$} & I & $253 \pm 188$ & $69 \pm 139$ & $46 \pm 28$ & $18 \pm 28$ & $37 \pm 23$ & $10 \pm 16$ \\
\hline & & \multicolumn{2}{|c|}{$\mathrm{p}<0.001$} & \multicolumn{2}{|c|}{$\mathrm{p}<0.001$} & \multicolumn{2}{|c|}{$\mathrm{p}<0.0001$} \\
\hline & \multirow[t]{2}{*}{ II } & $244 \pm 177$ & $68 \pm 125$ & $75 \pm 87$ & $24 \pm 62$ & $34 \pm 25$ & $9 \pm 17$ \\
\hline & & \multicolumn{2}{|c|}{$\mathrm{p}<0.001$} & \multicolumn{2}{|c|}{$\mathrm{p}<0.05$} & \multicolumn{2}{|c|}{$\mathrm{p}<0.0001$} \\
\hline & \multirow[t]{2}{*}{ III } & $249 \pm 84$ & $47 \pm 81$ & $71 \pm 71$ & $27 \pm 84$ & $43 \pm 37$ & $13 \pm 22$ \\
\hline & & \multicolumn{2}{|c|}{$\mathrm{p}<0.0001$} & \multicolumn{2}{|c|}{$\mathrm{p}<0.05$} & \multicolumn{2}{|c|}{$\mathrm{p}<0.005$} \\
\hline & \multirow[t]{2}{*}{ IV } & $274 \pm 195$ & $86 \pm 145$ & $65 \pm 35$ & $20 \pm 26$ & $52 \pm 35$ & $15 \pm 23$ \\
\hline & & \multicolumn{2}{|c|}{$\mathrm{p}<0.001$} & \multicolumn{2}{|c|}{$\mathrm{p}<0.0001$} & \multicolumn{2}{|c|}{$\mathrm{p}<0.001$} \\
\hline
\end{tabular}

\section{ANCA 関連血管炎における感染症対策(試案)}

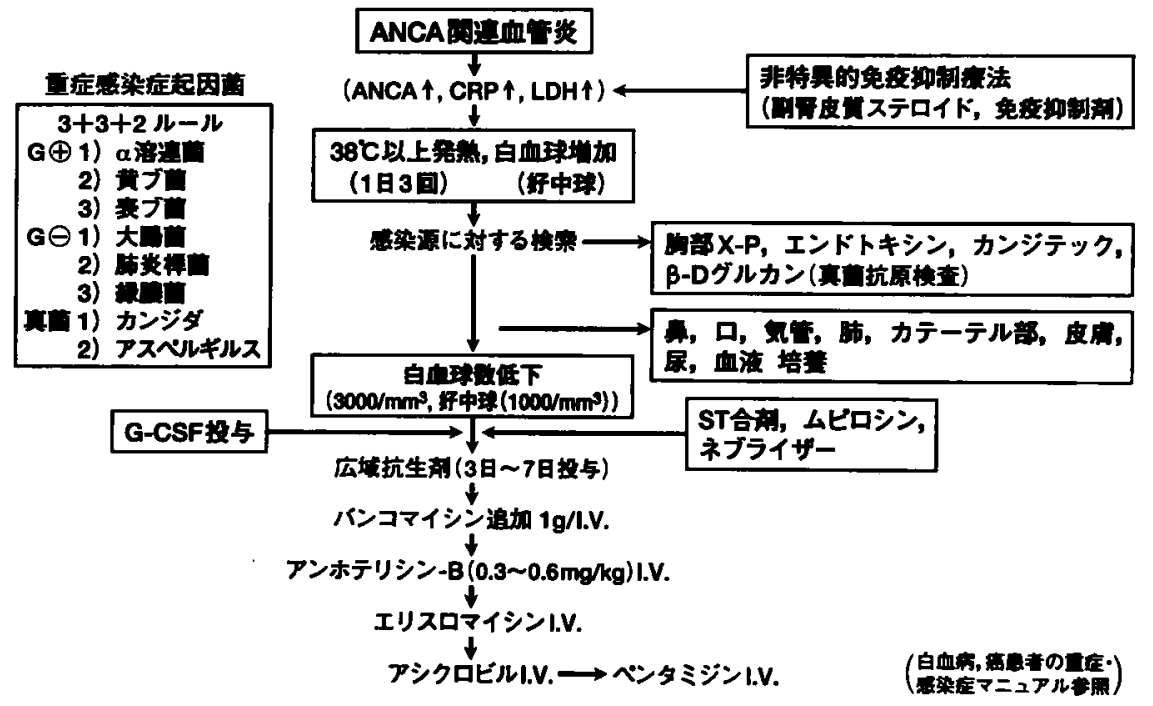

图 3

肺真菌症に対する対策が重要と考えられた。

ANCA 関連血管炎で感染症による死亡が最も多い ことは全国疫学調查の解析結果からも明らかにされて いる. 全国疫学調査における死亡例などを対象に感染 症のリスク因子を検討し，これをもとに免疫抑制療法 に対する感染症対策の試案を作成した（図 3).

5) ANCA 関連血管资の臨床的検討

1998 年に ANCA 関連血管炎の全国疫学調査を実施 し, 実態を把握した。PN 18 例, MPA 63 例, WG 28 例, AGA 12 例, その他の膠原病 33 例, 分類不能 の ANCA 関連血管炎 104 例 (UA syndrome), 計
266 例が集積された。男女比は $1: 1.7$, 推定発症年歯 は平均 57.4 歳, 発症より診断までの期間は平均 9.3 力月, cANCA 陽性は $26 \%, \mathrm{pANCA}$ 陽性は $81 \%$ の 症例に認められた。WGでは他疾患に比べ cANCA の陽性率が有意に高く, pANCA の陽性率が有意に低 い. 各疾患にそれぞれ特徵的な臨床像と検㚗所見を認 めた。UA syndromeでは, 腎症の早期出現率が高 く，他の疾患に比べ死亡率が高い，その死因は感染症 と肺出血が多く，全症例の検討においてもその傾向が 認められた（表 3).

MPO-ANCA 陽性 MPA は, 全身型, 肺腎型, 腎 
限局型に病型分類されるが，肺腎型で肺出血を認める 症例は急速進行性腎炎を伴い易い，また，血管炎の組 織像では，毛細血管炎型と毛細血管のみならず細・小 動脈にも血管炎が波及している壊死性血管炎型に分け られ, 前者では半月体形成性腎炎を伴う壊死性系球体 腎炎と肺胞隔壁炎の像を認め, 後者では多臓器に壊死 性血管炎を認めるが中動脈レベルまで病変をみること が少ないことも明らかにされた。

肺腎症候群をきたす疾患について検討すると, 腎系 球体営光抗体染色像で pauci-immune をる症例は MPA で, 高齢発症が多く, 高頻度に MPO-ANCA 陽性を認める。また, 肺腎症候群の症例と肺胞出血を みない半月体形成性腎炎の症例と比較すると前者は有 意に予後不良で透析導入率も高いことが示された。 pANCA は MPA, AGA, WG 以外の他の膠原病

表 3 ANCA 関連血管炎の死因

\begin{tabular}{lrr}
\hline \multicolumn{1}{c}{ 症例数 $(\mathrm{n}=52)$} & (\%) \\
\hline 感染症 & 19 & 36.5 \\
肺出血 & 9 & 17.3 \\
腎不全 & 7 & 13.5 \\
肺性心 & 2 & 3.8 \\
脳虚血疾患 & 2 & 3.8 \\
消化管出血 & 2 & 3.8 \\
DIC & 2 & 3.8 \\
呼吸不全 & 2 & 3.8 \\
間質性肺炎 & 1 & 1.9 \\
虚血性心疾患 & 1 & 1.9 \\
クモ膜下出血 & 1 & 1.9 \\
肺梗塞 & 1 & 1.9 \\
心不全 & 1 & 1.9 \\
不明 & 2 & 3.8 \\
\hline
\end{tabular}

においても認めることがあり，その予後は全国疫学調 查においてはUA syndromeに次いで不良である.

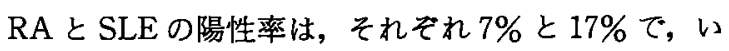
ずれも血管炎を示唆する症状が多く認められる.

\section{3. 臨床に関する知見}

1）大型血管炎

(1) 疫学, 疾患感受性遺伝子

これまで当研究班の対象疾患について全国疫学調査 を実施しその実態を明らかにしてきた。最近の疫学調 查は 1998 年に行われたが，この調査で側頭動脈炎の 実態が初めて明らかにされた. 表 4 に各疾患の疫学像 を示す. 大型血管炎にはバージャ一病, 高安動脈炎, 側頭動脈炎が含まれるが，バージャー病は最も症例数 が多く，男性に好発する。高安動脈病牥若年女性に好 発し，高齢者に好発する側頭動脈炎と対照的である. 地域差では高安動脈炎は日本を含むアジアに好発する が，側頭動脈炎は欧米に多く日本では少ないとされ る.

高安動脈炎は, 疾患感受性遺伝子として HLAB 52, B 39.2, DRB 1*1502, DQB 1*0601, DPB 1* 0901 と有意の相関のあることを明らかにしてきた. 今回, HLA 遺伝子群周囲の 5 つのマイクロサテライ トを用いリンケージ解析を行った. その結果, すでに 本症との相関が明らかにされている HLA-B 遺伝子 に加え, HLA 遺伝子近傍の IKB-like 蛋白のプロモ ーター上の多型と有意に相関することを明らかにし た.この蛋白の機能は未明であるが, 高安動脈炎との 関わりを検討する必要がある.

側頭動脈炎は，欧米では HLA-DR 4 との相関が明 らかにされているが，日本では未明である。バージャ

表 4 血管炎症候群の疫学像

\begin{tabular}{lcccc}
\hline \multicolumn{1}{c}{ 疾患名 } & 推計患者数 $(95 \% \mathrm{Cl})$ & 男女比 & 年齢分布 & 調査年度 \\
\hline 結節性多発動脈炎 & $1400(1200 \sim 1700)$ & $1: 1.1$ & 56.2 (平均) & 1994 \\
ウェゲナー肉芽腫症 & $670(570 \sim 780)$ & $1: 1.2$ & 46.2 (平均) & 1994 \\
アレルギー性肉芽腫性血管炎 & $450(370 \sim 530)$ & $1: 1.1$ & 47.1 (平均) & 1994 \\
ANCA 関連血管炎 & $2700(1900 \sim 2600)$ & $1: 1.8$ & 59.0 (平均) & 1998 \\
バージャー病 & $10000(8400 \sim 12000)$ & $9.7: 1$ & $45 \sim 65$ & 1994 \\
高安動脈炎 & 5000 & $1: 10$ & $35 \sim 65$ & 1993 \\
側頭動脈炎 & $690(400 \sim 980)$ & $1: 1.6$ & 62.5 (平均) & 1998 \\
悪性関節リウマチ & $4200(3200 \sim 5200)$ & $1: 2.2$ & 53.0 (平均) & 1994 \\
抗リン脂質抗体症候群 & $3700(3300 \sim 4000)$ & $1: 6.4$ & 40.8 (平均) & 1998 \\
\hline
\end{tabular}


一病では, HLA-B 54 ならびに HLA-DRB 1*1501 の 二つがそれぞれ独立して相関することを認めた。 た，高ホモシスチン血症がみられやすいとの仮説のも とに高ホモチスチン血症と相関するMTHFRの遺伝 子多型との関係を検討したが否定的であった.

(2) 診断, 臨床病態

高安動脈炎の臨床病態は侵される血管の部位により 異なるが，血管造影による障害部位により 5 型に病型 分類された，日本では，大動脈弓部に病変をみる I， II, V 型が多いが，中国，インドなどでは腹部大動脈 に限局するIV型が多い。これらの国では男女比は 1： 2 と男性の占める比率がより高い.大動脈弓に病変を みる症例は HLA-B 52, DR 2 が多いが, 腹部大動脈 に病変をみる症例は HLA-B 39 と相関し, 病型によ り相関する HLA 抗原, 人種が異なる.

側頭動脈炎では, 1998 年度の疫学調査によれば推 定患者数 690 名, 男女比 $1: 1.6$, 平均診断時年齢 71.8 歳である. 初発症状は頭痛が多く, 視力障害は 初期より $31 \%$ に認めた。リウマチ性多発筋痛症 (PMR) は $45 \%$ の症例に認め, 眼症状と両者併せ持 つ症例は $6.5 \%$ と少数であった. 死亡率は $4.5 \%$ であ ったが, 視力障害が重要視され, 眼症状と PMR は病 型分類される可能性がある.

高安動脈炎とバージャー病の重症度分類を作成し た.

（3）治療 - 予後 - 合併症

高安動脈炎に関する全国調査を平成 10 年より実施 しているが，それによれば通院患者のピークは50歳 代にあり高龄化がみられる．予後に関係する大動脈弁 閉鎖不全は $34 \%$ にみられる。この調查で登録された 患者について 1 年後の経過・転帰を再度調査した. 調 査対象は 611 名であったが, 1 年間の死亡率 $3.2 \%$, 再発 $8.1 \%$ で, 最も高頻度に出現した合併症は心不全 が最も多い. 次いで不整脈, 頭部乏血症状, 腎病変な どである，治療に関しては，ステロイド薬 $46 \%$, 抗 血小板薬 51\%, 抗凝固薬 19\%に用いられ，外科的手 術は $1 \%$ である。本疾患の重症度分類の推移を検討す ると $62 \%$ が変化無し, $25 \%$ が改善, $13 \%$ が恵化して いることが明らかとなった。

全国調查による側頭動脈炎の治療はほ涩全例ステロ イド薬が用いられているが, 合併症として感染症が最 も多い.

（4）遺伝子治療

バージャー病などにみられる重症虚血肢に対する遺
伝子治療の開発を目的として，虚血動物モデルの虚血 肢を用いて組み換えセンダイウイルスベクター (SeV) FGF 2 遺伝子を虚血肢の筋肉内に投与，ない し瀻維芽細胞に導入した AxCAMAssbFGF 遺伝子を 動脈内に投与することを試みた。その結果，いずれも 有効性を示唆する所見が得られ遺伝子治療の可能性を 示した（図 4).さらに, 臨床症例を用いて, バージ ヤ一病の虚血肢に対して血管新生因子の一つである肝 細胞増殖因子 (HGF) 遺伝子導入による治療の試み を開始した. 現在 4 人の患者に予備投与しているが， 重篤な副作用は認めていない.

(5) QOL

高安動脈炎, バージャー病患者の QOL について国 際的に使用されているQOL 評価法の Short Form 36 （SF-36）を使用して検討した結果，身体機能，日 常役割機能 (身体), 日常役割機能 (精神), 社会生活 機能, 心の健康, 体の痛み, 活力, 全体的健康の尺度 は，いずれも全般的な低下が認められた。

2） 中・小型血管炎

(1) 疫学

中・小型血管炎に含まれるPN, MPA, AGA, WG, 悪性関節リウマチ (MRA) の疫学像は表 4 に 示すごとく, 1994 年の全国疫学調查により明らかに されている. 1998 年に前述したごとく ANCA 関連血 管炎の全国疫学調查が実施され, 同時に抗リン脂質抗 体症候群 (APS) の調査も行われている. APSの推 計患者数は, 3700 名で, 男女比 $1: 6.4$, 診断時平均 年齢 41.3 歳である。基礎疾患を持たない原発性 APS は 44.9\%, SLE を含む二次性 APS は $55.1 \%$ を占め た. 動脈血栓症は $45.4 \%$, 静脈血栓症は $32.6 \%$, 習 慣流産・子宮内胎児死亡は $38.5 \%$ に諗められた。動 脈梗塞の $53.7 \%$ に脳梗塞が認められ, 主な死因でも あった。

(2) 診断・臨床病態

PN, WG, AGA の診断基準の修正を行い感度と特 異度の改善を図った。また, MPA を PNょり分離独 立し, 独自の診断基準を作成した. PN, MPA, WG, MRAの重症度分類を作成した。

（3）治療・予後・合併症

小委員会では, 1998 年に PN, WG, AGA, MRA の 4 疾患の予後に関する全国調査を実施した。PNで は, 古典的 PN (cPN), MPA, 皮膚型 PNを含め調 查した. 二次調查では, $\mathrm{cPN} 28$ 例, MPA 206 例 (腎限局型 66 例, 肺腎型 95 例, 全身型 45 例)，皮虞 


\section{bFGF group}

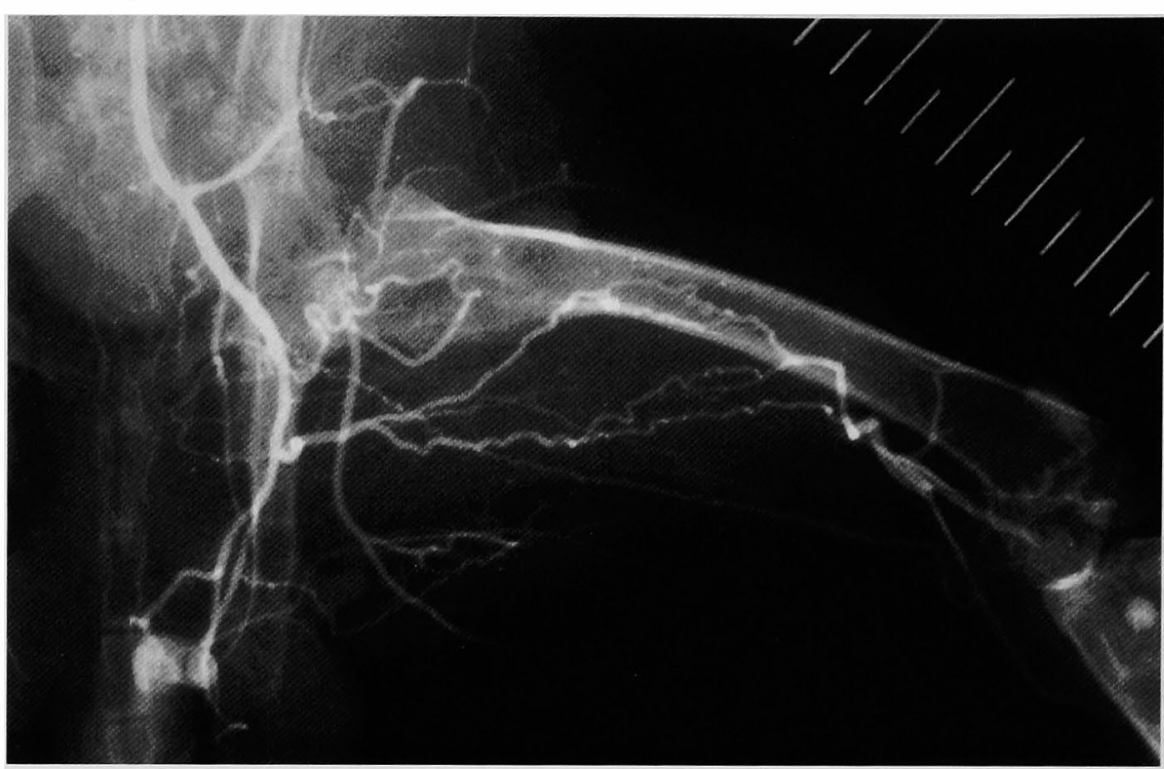

\section{Lac Z group}

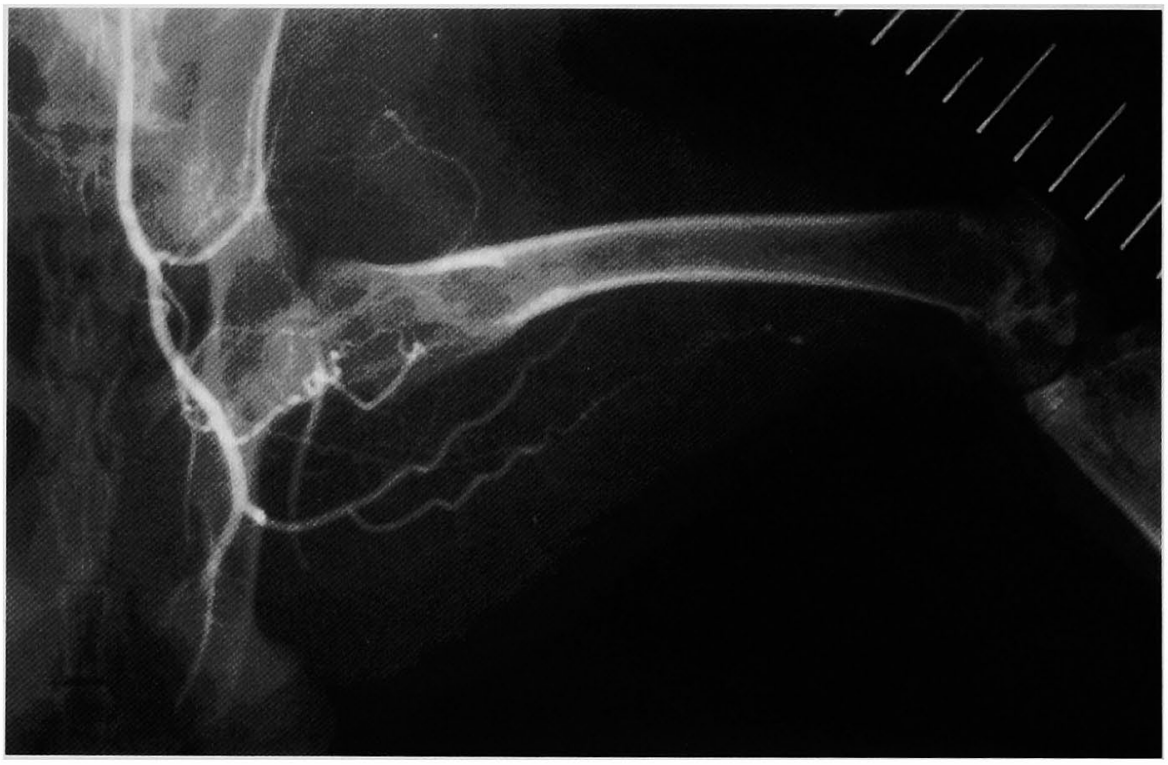

図 4 上段：ウサギ下肢慢性虚血モデルにおいて，IL-2 の分泌シグナルを挿入 した組換え bFGF 遺伝子をアデノウイルスベクターによりウサギ自家線 維芽細胞に Ex-vivo で導入し，虚血側内腸骨動脈に経カテーテル的に投 与し，有意な新生血管の発達による虚血の著しい改善を認める. 下段：対照として AxCALac Z ウイルスベクター導入細胞を用いた。

型 PN 11 例, WG 176 例（E 期 63 例，EL 期 40 例, ELK 期 73 例)，AGA 73 例，MRA 72 例 (Bywater 型 48 例，Bevans 型 24 例）の計 566 例が集積され た。各疾患の男女比，発症年齢は表 5 のごとくであ
る. 死亡率は $\mathrm{cPN}$ が $52 \%$ と最も高く, 以下, MPA $41 \%$, MRA 36\%, WG 21\%, AGA 14\%, 皮虔型 PN 0\%である. MPA の中では, 全身型 $52 \%$, 肺腎 型 52\%, 腎型 $13 \%$ であった。 WG では，EL 期 
橋本 - 厚生労働省厚生科学特定疾患・難治性血管炎に関する調査研究報告

表 5 全国予後調查における血管炎 6 疾患の男女比, 発症時年齢分布

\begin{tabular}{|c|c|c|c|c|c|}
\hline & 症例数 (例) & & 女 & 発症時年齢分布（歳） & 発症時平均年齢（歳） \\
\hline 古典的 PN & 28 & 21 & 7 & $13 \sim 83$ & 54.8 \\
\hline 顕微鏡的 PN & 206 & 104 & 100 & $16 \sim 88$ & 61.6 \\
\hline (腎型) & 66 & 34 & 32 & $16 \sim 84$ & 57.7 \\
\hline (肺腎型) & 151 & 50 & 43 & $17 \sim 88$ & 63.2 \\
\hline (全身型) & 45 & 20 & 25 & $19 \sim 90$ & 63.8 \\
\hline 皮盧型 PN & 11 & 3 & 7 & $15 \sim 77$ & 41.7 \\
\hline Wegener 肉芽腫症 & 176 & 73 & 100 & $12 \sim 86$ & 43.7 \\
\hline ( $\mathrm{E}$ 期 $)$ & 63 & 23 & 40 & $12 \sim 71$ & 40.4 \\
\hline (EL 期) & 40 & 20 & 19 & $14 \sim 78$ & 42.8 \\
\hline (ELK 期) & 73 & 31 & 41 & $8 \sim 77$ & 46.9 \\
\hline AGA & 73 & 30 & 40 & $16 \sim 86$ & 48 \\
\hline MRA & 72 & 27 & 45 & $13 \sim 79$ & 52.7 \\
\hline (Bywater 型) & 48 & 19 & 29 & $13 \sim 79$ & 52.7 \\
\hline (Bevans 型) & 24 & 8 & 16 & $23 \sim 78$ & 52.8 \\
\hline
\end{tabular}

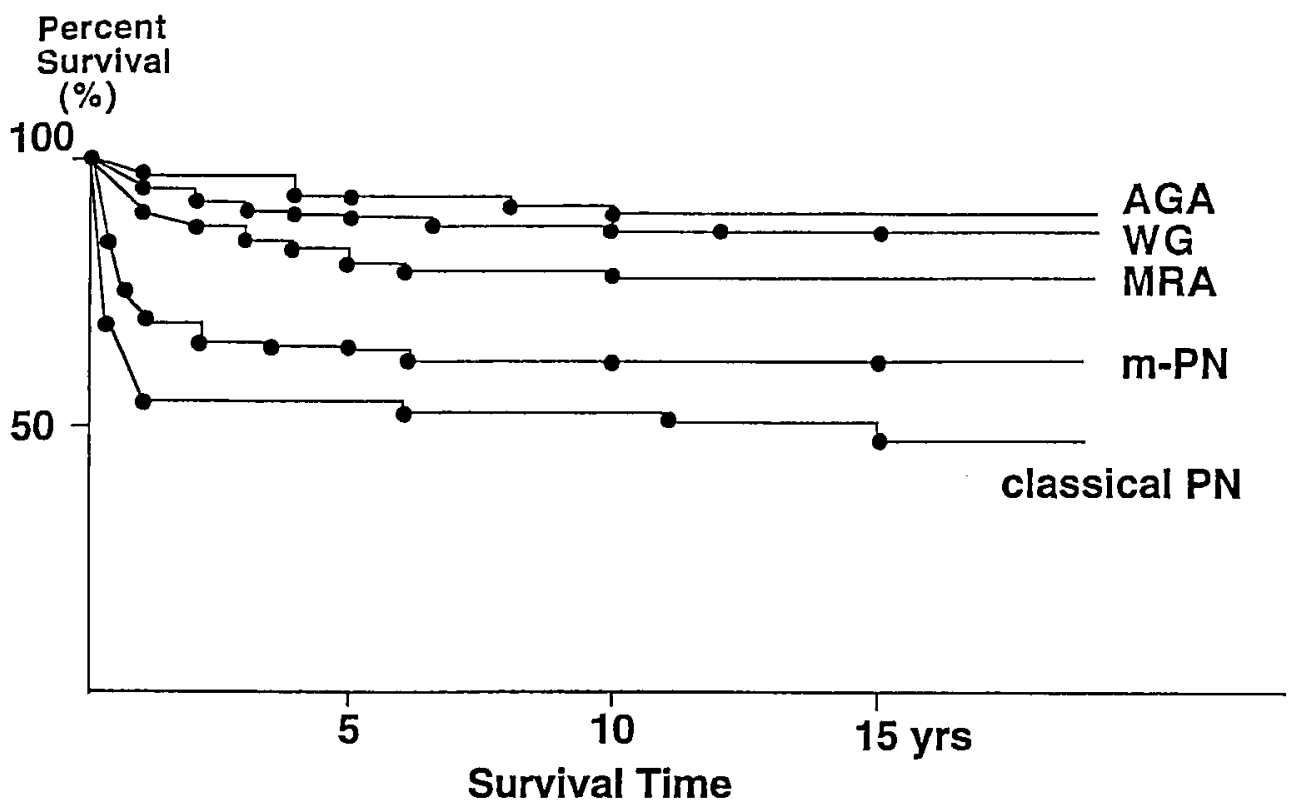

図 5 Survival in Five Collagen Vascular Diseases

$27 \%$, ELK 期 $13 \% ， \mathrm{E}$ 期 8\% で，MRA では， Bywater 型 29\%, Bevans 型 22\%である. 各疾患の 生命予後曲線（図 5) をみると, cPNの予後が最も 悪く，次いでMPA でいずれも 1 年以内に死亡する症 例が多い. 病型別では，MPA は全身型，肺腎型が腎 限局型に比べ予後不良で, 特に診断 1 年以内の症例の 予後が不良である.WG は EL 期, ELK 期の予後が $\mathrm{E}$ 期に比べ不良である. 1983 年の当研究班の全国疫 学調査の結果と比較すると, WG, MRA は共に著し い予後の改善が認められた。
免疫抑制薬の使用有無による予後を検討すると， cPN と AGA 除くMPA, WG, MRA では免疫抑 制薬の使用により治療後 2 年以上の長期的な予後の改 善がみられる。cPN, MPA，MRA では免疫抑制剤 使用群で感染症死の比率が高い傾向にあるが, WG, AGA ではその傾向は認められない.

(4) QOL

中・小型血管炎のQOL 評価法を確立するために short form 36（SF 36）日本語版および患者の症状, 所見を組み合わせた評価票を作成した。これを用いて 
中・小型血管炎患者 94 例の QOL について日本人健 常者と比較検討した結果, 8 種のサブスケールすべて において健常者に比べ偏差値が低いことを認めた。今 後, 疾患別による相違や同一患者の追跡調査などの検 討を行う予定である。

II. 終わりに

厚生科学難治性血管炎に関する調査研究班の最近の 知見を中心に記述した. 今後の更なる発展が期待され る.

文献
1）厚生省特定疾患免疫疾患調查研究班，難治性血 管炎分科会（分科会長橋本博史），平成 10 年度 研究報告書, 1999.

2）厚生省厚生科学特定疾患対策研究事業，難治性 血管炎に関する調查研究班（班長橋本博史），
平成 11 年度研究報告書, 2000 .

3）厚生労働省厚生科学特定疾患対策研究事業, 難 治性血管炎に関する調查研究班（主任研究者橋 本博史)，平成 12 年度総括研究報告書， 2001 . 